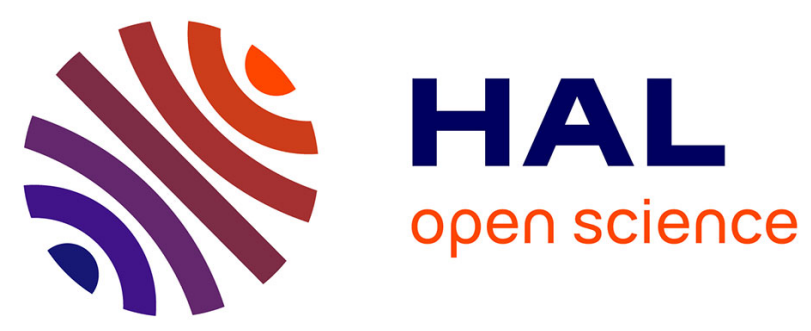

\title{
Transferring new dynamic capabilities to SMEs: the role of ONERA - the French Aerospace LabTM in promoting asymmetries management
}

Florin Paun, Nick von Tunzelmann, Philippe Richard

\section{- To cite this version:}

Florin Paun, Nick von Tunzelmann, Philippe Richard. Transferring new dynamic capabilities to SMEs: the role of ONERA - the French Aerospace LabTM in promoting asymmetries management. Innovation Forum: environment, Innovation and Sustainable development, Oct 2010, Marseilles, France. halshs-00560536

\author{
HAL Id: halshs-00560536 \\ https://shs.hal.science/halshs-00560536
}

Submitted on 7 Feb 2011

HAL is a multi-disciplinary open access archive for the deposit and dissemination of scientific research documents, whether they are published or not. The documents may come from teaching and research institutions in France or abroad, or from public or private research centers.
L'archive ouverte pluridisciplinaire HAL, est destinée au dépôt et à la diffusion de documents scientifiques de niveau recherche, publiés ou non, émanant des établissements d'enseignement et de recherche français ou étrangers, des laboratoires publics ou privés. 


\title{
Transferring new dynamic capabilities to SMEs: the role of ONERA - the French
} Aerospace $\mathrm{Lab}^{\mathrm{TM}}$ in promoting asymmetries management

\section{Florin PAUN*, Nick VON TUNZELMANN** and Philippe RICHARD***}

\author{
*Deputy Director Industrial Innovation, ONERA-The French Aerospace Lab ${ }^{\text {TM }}$ \\ ** Emeritus Professor, SPRU, University of Sussex \\ ***Partner, ID Vector
}

\begin{abstract}
(ABSTRACT)
The technology transfer process between a public laboratory and a company has been the subject of many publicationsand has been widely discussed in economic theory. This paper highlights several newly identified asymmetries occurring between the different agents taking part in the process, dealing specifically with the aerospace and defense sectors in France.

These specificities concern the characteristics, capabilities and competencies (the 'capacities') of French SMEs and public research laboratories. The theoretical corpus of the article draws partly upon the analyses of 'dynamic and interactive capabilities' (and competencies), and for the rest upon empirical sources, being based on the recent experience of one of the most dynamic Technology Transfer Offices (TTOs) in France: the case of ONERA (the National Office for Aerospace Studies and Research) and its dyadic relations with the SMEs.

In such a cooperative, interactive innovation process, we will argue that certain collaborative tools or practices emerge, aimed at reducing information asymmetries or acting as compensation mechanisms for other types of asymmetries between the partners at a microeconomic level; especially in France where there is a gap between the public R\&D laboratories and the SMEs in terms of Technology Readiness Levels (TRLs). Some of these compensation mechanisms, particularly those related to the knowledge economy,could be adapted and reshaped for agents engaged in R\&D and innovation in various other sectors, perhaps inducing positive amplification effects on innovation behavior, and thereby on economic growthat the macroeconomic level within the "national innovation system".
\end{abstract}

Keywords: French SMEs, technology transfer, information asymmetries, dynamic capabilities, innovation systems 


\section{INTRODUCTION}

The technology transfer process between a public laboratory and a company has been the subject of many publicationsand has been widely discussed in economic theory as well as in applied economics (e.g. in the Journal of Technology Transfer). Here we will deal with the specificities related to this process in France and, in particular, in the field of technology transfer arising from the field of aerospace and defense.

These specificities relate to the characteristics, capabilities and competencies ('capacities') ofSMEs and public research laboratories. This paper will be based mainly on feedback regarding the strategy implemented for the development of an economically 'healthy' relationship between ONERA (Office National d'Etudes et Recherches Aérospatiales, the National Office for Aerospace Studies and Research) and the SMEs surrounding it with mostly dyadic relations between themselves. The choice and definition of collaborative tools will be explained together with the analysis of the initial resultsand the prospects envisaged.

We will contend that, in a cooperative process of innovation, these tools become mechanisms for reducing informational asymmetries (Stiglitz \& Weiss, 1992) or "compensation mechanisms" (Paun, 2009) for other asymmetries between the variousplayers at a microeconomic level. These newly identified asymmetries, Institutional asymmetry (regarding the institutionalist theory of Veblen, 1914), Technological asymmetry and Risk asymmetry, often act as barriers to the technology transfer process, while simultaneously being critical for the eventual high intensity of the innovations pursued. The greater are the asymmetries, the stronger will be the impacts on the intensity of innovations, always supposing that the differently involved actors in the innovation process do succeed in working together. This involves the effective implementation of asymmetries reduction (compensation mechanisms), through 'blending' the capacities for change of the various agents.

Some of these mechanisms, more related to the knowledge economy,could be adapted and reshaped for other agents in the $R \& D$ and innovation domain, and for evaluation or regulationauthorities of this domain. Their implementation for these other players could induce an amplification effecton innovation and its direct effects on economic growthat the macroeconomic level within the framework of the "national innovation system" (Freeman, 1987; Lundvall, 1992; Nelson, 1993).

\section{THEORETICAL ISSUES}

In appealing to a systems approach, in accounting for the points of conjuncture and disjuncture between small companies and large establishments, and between research labs and aerospace/ defense companies/contractors, we are thinking of both the vertical elements - here the progression from micro-level (of individual agents, like people and organizations) via the mesolevel (of individual sectors and/or regions) up to the macro-level (of national systems) and even global levels - and of the horizontal dimension, here the various types of asymmetry incurred by the various types of organization with which we are concerned, viewed both individually and collectively.

\section{I.1 Meaning of 'capabilities'}

The line of argument we shall pursue is given by the recent popularity of the so-called 'dynamic capabilities' school, as launched by David Teece and his colleagues in the 1990s (Teece et al., 1997, etc.). Both words however fall into a category described by the eminent Austrian economist from the middle of the 20th century, Fritz Machlup (1959), as 'weasel-words', i.e. words that promised the hope of clarification but ended up just sowing more confusion, through their very presumptuousness; or more simply, words that mean less than they first appear to say. 
Mindful of such problems, Teece et al. thus define dynamic capabilities in terms of 3 P's, namely position and paths, which define the dynamics, together with 'processes', which we can interpret as 'business processes', i.e. what we will term the 'functions of the firm', and this brings them close to our own final definition as provided below. These authors do not distinguish between capabilities and 'competencies' in their descriptions of the meanings, which is precisely where our own study takes off from.

Our approach, in brief, is to assess what 'capabilities' are through adapting Nobel Laureate Amartya Sen's concept of 'consumer capabilities', ${ }^{1}$ according to which capabilities comprise the ability to consume the product effectively, together with the circumstances constraining that consumption process (e.g. the financial and legal environment in our case, or the 'entitlements' to income in Sen's situation of famines). 'Ability' to consume involves both the competencies acquired by purchasing ${ }^{2}$ skills from other sources and capabilities proper, learnt within the organization. 'Capabilities' in this sense represent an intermediate transformational concept between orthodox 'characteristics' of a product, or technology, etc. (see Gorman, 1956; Lancaster, 1966) and the orthodox set of 'rewards' (or motivations) for making use of the characteristics for some stated purpose (e.g. utility in Sen's case of consumer capabilities). 'Capabilities' are highly heterogeneous as between individuals or organizations, in terms of both their differentiated nature, and the amounts with which each individual or organization is endowed (or dynamically able to enhance them through learning).

Table 1 clarifies the distinction drawn in our analysis between capabilities and 'competencies', pointing out the need for both in order for a region or country (or individual firm or industry) to be able to claim its capacity with regard to full dynamic capabilities. ${ }^{3}$

Table 1: Competencies vs. Capabilities: Essential differences

\begin{tabular}{lll}
\hline Essential: & Competencies & Capabilities \\
\hline 1. Function & Enhancements to 'resources' & Enhancements to 'services' \\
2. Stocks & Human and R\&D capital stocks & Knowledge stocks \\
3. Chain position & Inputs related & Outputs related \\
4. Product area & Specific, focused & General, adaptable \\
5. Supply-demand & Supply driven & Demand and supply driven \\
6. Stage & Potential & Realised \\
7. Development & Acquired and/or hired & Accumulated within \\
8. Learning & Learning by searching (STI) & Learning by doing (DUI) \\
9. Dynamics & Externally available as needed & Internally deployable in real time \\
\hline
\end{tabular}

The sum of competencies and capabilities then gives us a figure for 'capacity', as in building capacity both external and internal resources need to be meshed together. Such a meshing or 'blending' process is contrary to the difficult alternatives of blocking or bridging proposed by Putnam et al. (1993). We shall return to this point in discussing interactivity below.

\footnotetext{
${ }^{1}$ Defined for very different purposes by Sen (e.g. for famines in poor countries; see Sen, 1985, etc.).

${ }^{2}$ Even if there are no monetary charges for this acquisition process, there must be opportunity costs of the time etc. involved, as in Friedman's celebrated concept of there being "no such thing as a free lunch" - without even attempting to cost up the risks involved in changing one's skill base (see below).

${ }^{3}$ The list here is loosely based on that given by von Tunzelmann (2009) which also lists a further 8 'associated' differences, regarded as less definitive and more by way of elaboration. Key pointers to the definitional differences are probably points (1) - functional differences, and (7) to (9) - the dynamics.
} 
This three-tiered and nested approach is then extended by our research (e.g. von Tunzelmann \& Wang, 2003, 2007; von Tunzelmann, 2009, etc.) to producer capabilities (involving production of all kinds and not necessarily standard manufacturing processes), drawing for this purpose on Edith Penrose's theory of the 'growth of the firm' (Penrose, 1959) and also to 'supplier capabilities', where issues of IPRs may become paramount because of possibilities for appropriation by giant firms. Thus in Figure 1 there are 3 types of actors, which occupy the full area of prospective agents. From a supply chain or supply network perspective, all actions are ones of production or consumption or supply, and often all three at the same time. Thus in the process of producing this paper, intended for the consumption of various types of readers including policy-makers as well as academics, there is therefore a 'forward linkage' to users, in addition to 'backward linkage' (in the sense of Hirschman, 1958) to our suppliers - on this occasion the accumulated wisdom of our forebears, plus the accumulation of technology in the form of instruments and artifacts, like computer hardware and software, This $3 \times 3$ matrix thus applies quite generally to any form of production, whether governmental (producing policies, etc.), or academics (producing research papers), or firms (producing products), however different the actual production processes are and also the conditions of governance. Most of these are in fact multi-agencies, whereby academics produce students and consultancy reports as well as 'papers'; governments produce physical and social infrastructure as well as policies; increasingly one finds manufacturing companies producing services alongside their traditional goods, etc. (Davies \& Hobday, 2005). Note that we find it useful to distinguish between agents, as the physical embodiments of people or the organizations to which they belong, with either being represented by its name, and actors, representing the multiple roles that nearly all agents will have to play. Not surprisingly, perhaps, we have to relax this distinction in our discussion to follow, where we shall be taking ONERA as 'the' technology supplier and the SMEs as 'the' customers.

Figure 1: The model of capabilities in the technology supply chain

\begin{tabular}{|c|c|c|c|}
\hline Actors. & $\begin{array}{l}\text { Suppliers } \\
\text { (technology) }\end{array}$ & Producers & Consumers \\
\hline Characteristics & $\begin{array}{c}\text { S\&T } \\
\text { possibilities }\end{array}$ & $\begin{array}{l}\text { Production } \\
\text { possibilities }\end{array}$ & $\begin{array}{c}\text { Product } \\
\text { possibilities }\end{array}$ \\
\hline Capabilities & $\begin{array}{l}\text { Technological } \\
\text { capabilities }\end{array}$ & $\begin{array}{l}\text { Producer } \\
\text { capabilities }\end{array}$ & $\begin{array}{c}\text { Consumer } \\
\text { capabilities }\end{array}$ \\
\hline Rewards & IPR returns & Profitability & Utility \\
\hline
\end{tabular}

In the figure, the markets operate effectively, though they are limited to being the outcome of exercising capabilities and competencies. In the row of characteristics, there is first the matching of the supply of and demand for technology (NB a 'derived demand', depending on the next market along, which is the one given here in the final column as the match between the supply of and demand for products). There are mirror image mappings to those from the capability vector to that of characteristics, in the mappings from capabilities to motivations, or 'rewards', again

\footnotetext{
${ }^{4}$ cf. von Tunzelmann, 1995, p. 2.
} 
inserting a physical differentiation into a value-defined space (here 'profitability' rather than prices though). Finally there are non-market exchanges which take place directly among the agent producers themselves, with the horizontal arrows typically representing asymmetries of knowledge between the agents and the respective capabilities.

\section{I.2 Dynamic and interactive capabilities}

The first 'static' version of the approach as discussed so far via Figure 1 can then be straightforwardly extended further to the context of interactive learning (Lundvall, 1992), and hence to 'dynamic capabilities' proper (Teece et al., 1997). As shown in the diagram, the interactive elements are partly mediated through market mechanisms relating to supply and demand factors, in connection with both the characteristics (product possibilities, etc.) and the rewards (profitability etc.); however the most interesting form of interactive learning consists of direct interchanges of knowledge among the actors, shown by the two-headed horizontal arrows in Figure 1. Although this is often represented as 'absorptive capacity', we take here the opportunity for a more proactive role, of 'giving as good as one is getting' through reciprocity in networks and partnerships. This might be termed the third face of $R \& D,{ }^{5}$ following the first face of original technological development and the second face of the ability to reproduce the technological results of others - this third face indicates what the company or other recipient agent can bring to the negotiating table in terms of the stage of knowledge acquisition.

In these respects there is already a dynamic component to interactive capabilities, but strictly speaking dynamic capabilities in our sense of the term concern responses in real time to stimuli, such as would be emitted by market competition or technological change. 'Real time' here signifies a period of time which extends for just long enough to capture some or all of the potential rewards from the innovation. The emphasis lies on speed - being in the first place ready Innovations, Cahiers d'économie de l'innovation, vol. 2008/2, no. 28, Economie de la Défense, Finance et Innovation, pp. 61-83.

Stephan R., 2006, "Which practices for universities to enhance exchanges and transfer?", presentation at the French American Foundation seminar "Research \& Innovation: Best Practices for the Future", University of Compiegne, Paris.

to hand to match the new requirements, i.e. any suitable set of human and non-human resources, while the latter is more a question of adequate entrepreneurial flair. All of this accounts for our stress on speed and catching-up in real-time activities of the organization.

Relationships posited can be thought of as linked dyads, with alternative time sequences (i.e. with the supplier-producer links and producer-consumer links preceding or succeeding each other in rather random fashion). The effectiveness of such links depends on the motivations (incentives of expected profitability etc.) but also the 'capabilities' for operating the links, on both sides of each dyadic relationship.

\section{I.3 Dynamic scale and scope economies}

Such gains in speed come at a cost, as reflected in time-cost trade-offs (Scherer, 1967). To justify themselves they must cover these and any ancillary costs over the medium to longer run. We shall pursue them below in the guise of so-called 'limit curves', by sector. These 'dynamic' scale economies most often arise at a systemic level; e.g. the increasing prices of an 'average' microprocessor unit ('chip') over time as the complexity rises is more than offset by the downstream impacts of much faster speeds of working and much higher levels of integration, according to the operation of 'Moore's Law'.

\footnotetext{
${ }^{5}$ The reference here is to the seminal paper by Cohen and Levinthal (1989), which discusses the first 'two faces'.
} 
Economists have become accustomed to talking about economies of scope as well as of more traditional scale, even though there is an inherent tension between the two concepts when applied in practice. Putting the argument another way, there would seem to be an inherent trade-off between economies of scale and economies of scope. While vertical integration generally requires large plants in most manufacturing industries (e.g. integrated steel mills), horizontal integration, i.e. at a specific product or technological level, can often be achieved by using smaller-scale production methods, in order to reap the synergies on offer from economies of scope at other levels, e.g. mini-mills in steel. It is worth emphasizing at this point that economies of scope, just like economies of scale, can arise in any of the functions of the firm or other organization under analysis, e.g. in marketing or in finance, and not necessarily in production or technology.

Dynamic scale and scope economies are of two main kinds, One is the long-term secular improvement associated typically with infant industries and their protection, often as part of a catching-up strategy of development. The second way, which is of more concern to us here, is through short-term, real-time gains that reflect speeding-up behavior, e.g. in big business, where Chandler (1977) refers to increased throughput in production and increased stock turnover in distribution (marketing). Such gains, which despite arising in the short run tend to be quasipermanent and quasi-irreversible, are what we term 'time-saving' (von Tunzelmann, 1995), and are as already indicated crucial (or so it is alleged) in the resort to networking by individual firms. They do so in order to leverage their own 'home-grown' capabilities through acquiring competencies from other organizations.

\section{I.4 Dynamic appropriabilities}

Commensurate with such dynamic scale and scope economies at the production possibilities level there are dynamic appropriabilities to be reaped at the rewards level. In much the same manner, these potentially arise out of being quicker or more accomplished at seizing the market or technological opportunities going. Thus, as Reinert (1994) has stressed, developing countries have tended to place too many of their hopes on the perfection of markets for their export goods, without allowing sufficiently for the fact that it is turning imperfect markets to one's advantage that secures the highest private gains from trade.

Our own position when it comes to looking into the economic dynamics of appropriabilities reflects our views of dynamic scale and/or scope economies, namely that they have to do with developing speedy responses to constantly changing circumstances, such as are associated with continual incremental technical change and product development. More specifically these may emerge in such respects as opening up lead times over rivals, changes in corporate or brand reputations, changing patterns of trade secrets, etc. And whereas traditional static forms of IPRs include such aspects as patents, trademarks and copyright, the newer 'anti-IPR' elements incorporate such (ostensibly) radically different opinions as 'open-source' software, 'copyleft', etc.

\section{CONTEXT, POSITIONING AND ROLE OF THE ACTORS IN INNOVATION}

A brief description of ONERA's economic environmentis necessary for a better understanding of the reasons for the tools it uses and disseminates, and their operation, as well as being a reminder of the fundamental principles of innovationand the role of technology transfer therein.

ONERA is a scientific and technical public corporationwith commercial andindustrial characteristics (EPIC), created by Law no. 46-895 on May 3rd 1946 and modified by decreesno. 63-385 and no. 84-30. Its mission is defined as follows: “... to develop and direct research in the aerospace field; to design, develop and implement the necessary technical tools and benches for carrying out this research; to ensure, in association with other $R \& D$ organizations, the 
circulation, at a national and international level, of the results of this research; to support their utilization by the aerospace industry; and possibly to facilitate their application outside the aerospace field". Thus its mission so far as interactive capabilities are concerned is to diffuse them as widely and rapidly as seems feasible.

The quotation just given is important for understanding ONERA's position in the $\mathrm{TRL}^{6}$ chain (Mankins, 1995), its role in technology transfer, and more generally its role in innovations generated on the basis of the technology that it has created.

So the legal text gives a futurology mission toONERA “... to develop and direct...”, a mission as originator and ownerof experimental resources, to circulate the results and to be a discriminatory facilitator(for the national and European industry) for the creation of value "...to support utilization..."

This nuanceis very important, particularly in the 'ideological opposition' between those who prioritize a 'publication' strategy and those who prefer one that stresses a 'patent',because premature disclosure, in the form of articles or conferences, ensures the circulation of knowledge but also facilitates uncontrolledutilizationof the results of research by industry, including competitorsof the national or European industry. However we should recall from our analytical study already reported in section I.4 above that this gives a somewhat loaded view of IPRs, focusing on static results, to the possible detriment of longer-term dynamic gains.

It must also be observed that ONERA has to transfer the results of its research(in order to "... support utilization...") to the aerospace industry and also "... outside the aerospace field..."

Its supervisory authority is the Head of the French national armaments organization (DGA). The other organizations with which ONERA has close relationshipsare the DGAC,CNES, the ESA ${ }^{7}$ and of course the European Commission (EC) through contracts that are part of the PCRD ${ }^{8}$. Its strategic customer-partners are the large French or European aerospace groups,such asAirbus, Eurocopter, Astrium, Snecma, Thales and Dassault. During its entire existence ONERA has devoted most of its activities to studiesdirected by or for this first circle of institutional or industrial partners.

The last consolidated figures show an annual operational budget of $€ 187 \mathrm{~m}$, of which $57 \%$ comes from R\&D service contracts, and a labor force of 2047 employees.

\section{II.1 - Specificities of the Aerospace and Defense field}

This brief description of ONERA's economic environment needs a complementary analysis of the players from the point of view of the utilization of its research results by industry.

Hence Figure 2 presents a classification of the market sectors according to two parameters: the time involved in launching products resulting from a new technology in the market, and the complexity of the products intended for this market, roughly approximated by the cost of a unit of the product(Stephan, 2006).

Stephan, in presenting this figure, proposed a generic limit to innovation process control (up to the successful delivery of the new good and/or service to the market) by the carrier-creator of the technology itself. The originally defined curve, of the kind already noted in our survey in Part I above, supposes that a new product requiring very low development costs or complexity could be introduced to a market if time were expandable. We consider that for a low complexity product with low development costs many actors could proceed to develop this type of new product. Its time for introduction to the market will depend mainly on its acceptability by the

\footnotetext{
${ }^{6}$ Technology Readiness Levels

${ }^{7}$ Respectively: General Directorate of Civil Aviation; National Center for Space Studies; European Space Agency

${ }^{8}$ Research and Development Framework Programme
} 
consumers. As soon as they can accept the new product, everybody could provide it. Thus the time will be cut short instead of being expandable (or else the product will never be introduced because of never getting accepted).

The original defined curve supposes also that a new product requiring unlimited development costs with exceptionally high complexity could be introduced in a market only if it could be delivered in a very short time ('real-time'). The development means are assumed to be limited even in a large industrial group. This will induce a limit on engaging costs for any economic agent.

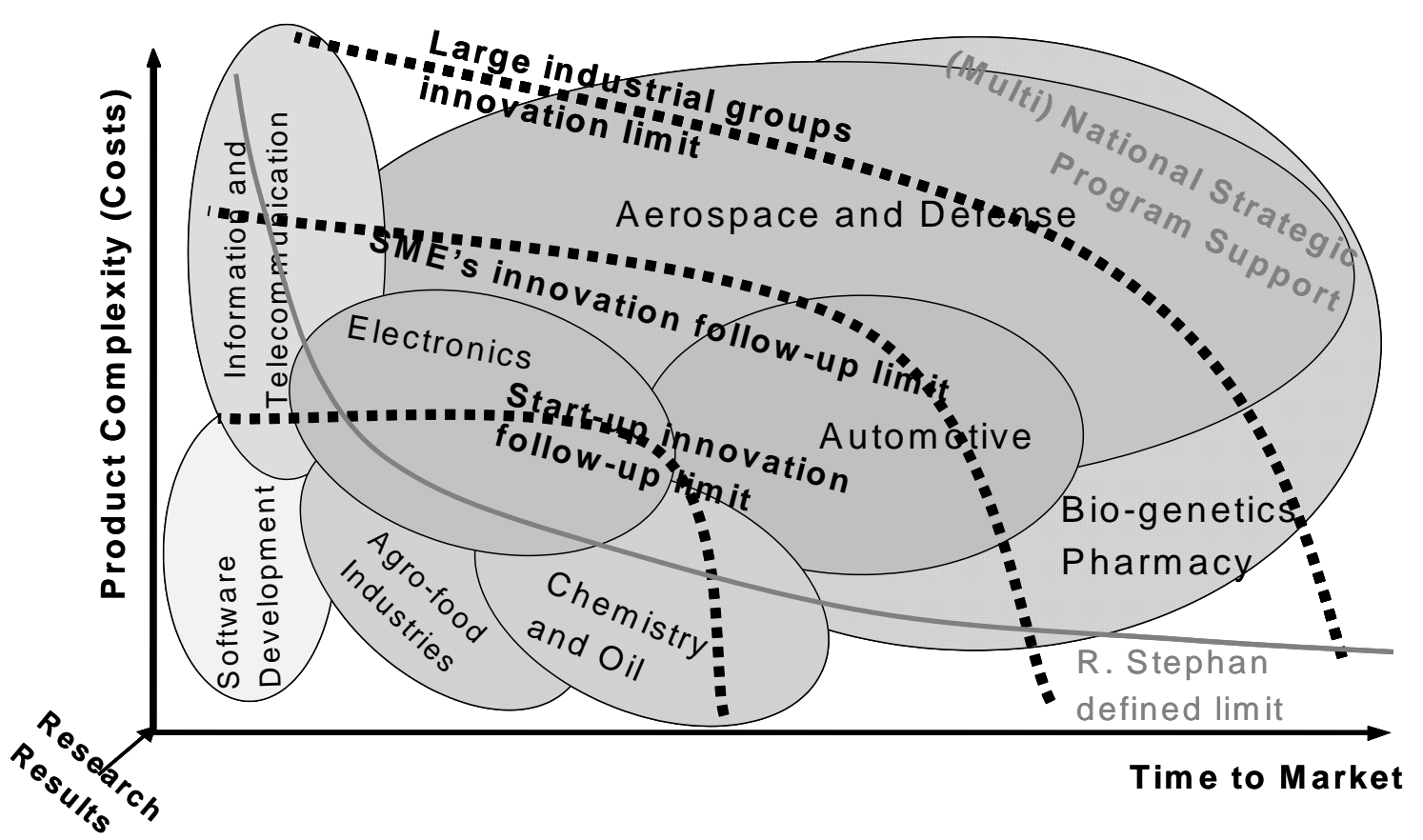

Figure 2: Limits to innovationprocess control by the creator (or assimilator) of technology, by technological sector: - R Stephan's limit - - Authors' proposed limits

Acknowledging this analysis with Stephan, we nevertheless contend that this generic limit curve has to be transformed in an elliptic type curve from an initial hyperbolic type, of the kind encountered previously in discussing time-cost trade-offs above. The basic reason for abandoning the hyperbolic shape is derived from considering the sectoral space here and thus the (approximate) sectoral contrasts.

It also must be admitted that an SME has less material means to establish a successful new good/service in the market than a large group. This is even more evident for a start-up partner. Thus we also propose to divide the limit curve into three branches corresponding to these three types of agents. These new proposed limits are generically represented in Figure 2.

The specificity of the aerospace and defense markets asserts itself very quickly because these sectors, which are generally 'complex systems' (Davies \& Hobday, 2005),require a lot of time for the development and introduction of a new product to the market. We note that even large groups, beyond a certain limit,need institutional support at the national level, if not at the international level, to develop new technologies.

So in what circumstances would ONERA be able to respond wellto its futurology mission of "developing and directing research" and its transfermission "to support the utilization of its results bythe national industry"? 
By being located within the upper limit of the diagram, the large aerospace sector and French and European defensegroups stand out as designated partners for successfully 'bearing', i.e. acting as generator, carrier and user of (hence, all the 'actor' roles for) the new technologies suggested and/or developed by ONERA. This is particularly the case for the incremental or specialized innovation of the large groups. Such 'bearing' is however less obvious in the case of technological breakthroughs(see McCooe, quoted inGolob, 2006), and this is even more the case in the civil aerospace sector where technologies used on-board planesmust be safe and tested. For these aspects, since its creation ONERA has developed and maintained effective strategic partnerships with the large national groups which have mostly become multinationals in recent years. This partnership policy will not be the subject of our analysis here.

The fundamental question raised during the development of ONERA's implementation strategy is that of access to markets, for breakthrough technologies resulting from a specialized research sectorsuch as aerospace. From this point of view, the preceding diagram, presenting the limits to innovationprocesses, illustrates the point that, to put a 'breakthrough technology' on the market, thus challenging the existing products and/or business models, such as may be designed by a national skill centre, the best vectors are the SMEs. This provides the systemic element of the dynamic scale economies already referred to in Part I.

Technological demonstrations that result in innovation will not necessarily take place in the aerospace market but can arise in any of the market sectors in which the SME receiving the technologycan itself control the innovationprocess completely(until the successful introduction of the new product to the market). Some niche markets will be accessible, even in the aerospace sector(green aviation, small-scale drones, leisure, etc.).Once the technology is demonstrated, there are strong chances that the large aerospace groups will integrate this technology as a tested module into the systems they are designing(Mouchnino \& Sautel, 2007).

The strategic choice was taken at ONERA to develop a partnership relationshipwith a national and European SME. If no SME is identified, the launching of a start-up partner could be studied, subject to the economic outlook and adequate financial support.

\section{II.2 - ONERA-SME Relationships}

Like any healthy dyadic partnership, that between ONERA and an SME must be a winning one for both parties. Both partners must have strong positions(Cowan, Jonard \& Zimmermann, 2003) with each adopting its own role so that their collaboration generates significant added value. So ONERA develops its best technological solutions, possibly breakthrough technologies, and the SME implements its product development, industrialization and marketingcapabilities in order to reinforce its competitive advantage in its markets or to create new ones.

These complementary roles, based for one side on a 'craftsman instinct' and for the other on a 'predatory instinct', opposable in the sense given by the theory ofVeblen (1899), generate significant asymmetries between the two partners.

Figure 3 presents the existing asymmetries between the public R\&D laboratories and the SMEs in France by showcasing their respecting positions with regard to the TRLs (Mankins, 1995); ${ }^{9}$ it should be stressed for joint projects. It relies on simple and tested principles of «win - win » and « give - give », providing benefits for each participant, as summarized below:

\footnotetext{
${ }^{9}$ This figure was first presented and generally accepted at the 'Rendez Vous Carnot', Lyon, France, 2010, in the last Round Table dedicated to collaboration between Carnot Institutes and the SMEs.
} 


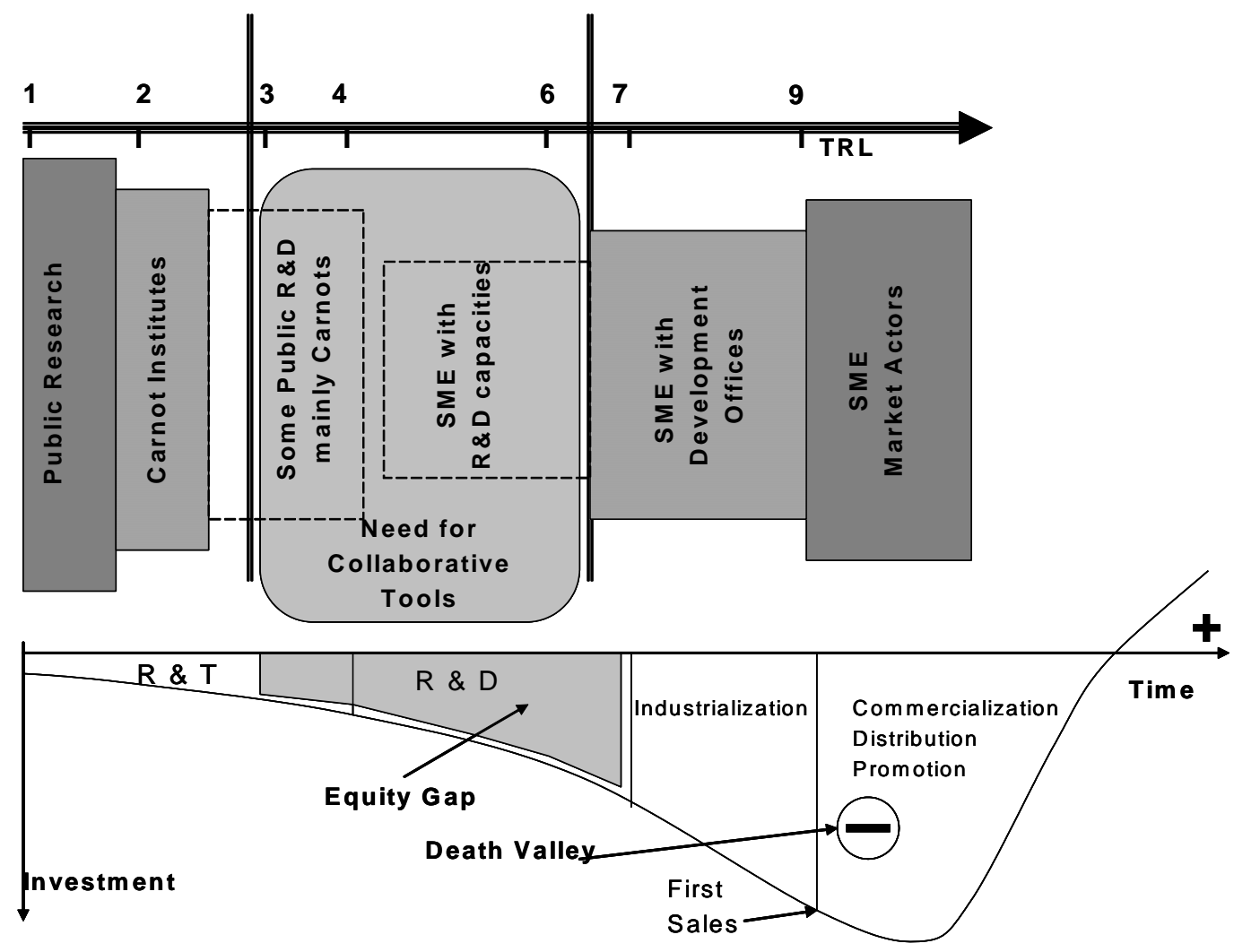

Figure 3: Asymmetries between public R\&D laboratories and SMEs, by TRL score

It should be emphasized that the majority of the public R\&D laboratories in France carry out their activities at levels TRL 1 (basic research) and TRL 2 (applied research). The 33 Carnot Institutes, being responsible in [AI Carnot, 2008] for some $€ 470$ million of research carried on in partnership with industry, and representing about a half of the yearly budget for French research undertaken in partnership with industry, are generally well involved in applied research (TRL 2). Very few of the Carnot Institutes could carry their research up to laboratory demonstration levels (TRL 3-4). Exceptionally and limited to particular programs, some of the Carnot Institutes could bring their technology to operational levels (TRL 6-7).

Beside these figures, the SMEs are currently running their business at TRL 9 (these are selling products, services or components). Fewer than 10\% of French SMEs have Development Offices able to integrate (or absorb) operational prototypes (TRL 6-7), in order to structure production chains and introduce new products to the market. And even fewer have R\&D capacities able to understand technologies available at Lab Demonstration Levels (TRL 3-4). Thus, the technological asymmetry existing between public R\&D labs and the SMEs becomes obvious.

In addition, is well known that between the same levels an equity gap is evident in some European countries, hence the European Investment Fund (EIF) and several public-owned banks (like CDC in France) have dedicated important financing programs to compensate for this Europe-specific 'amorçage' equity gap. This of itself will induce an important risk asymmetry between public R\&D and the SMEs.

These asymmetries must be reduced (for the informational asymmetries) or compensated for (technological capacities, financial and institutional risks) in order to support this new codevelopment relationship between the parties, as put forward in this analysis. The collaborative tools will thus be reduction and/or compensation mechanisms for the existing asymmetries between ONERA and its SME partners, with the aim of creating a trust environment between the two agents. 
Owing to their small size (INSEE, 2008) but also to the structural weaknesses of the innovation support system set up by SMEs and/or start-up partners in France (Serfati, 2008; Levy \& Jouyet, 2007), French SMEs must have suitable support mechanisms (private or public) for the success of a possible common development program with ONERA, in order to absorb new technology and to make a success of their international commercial deployment.

Two different approaches were targeted by ONERA's Technology Transfer Office (TTO). More than $3 / 4$ of the signed agreements were obtained through a Market-Pull approach and under $1 / 4$ were obtained from a Technology-Push approach. Figure 3 supports this part of our analysis.

Indeed, following an intensive advertising campaign based on slogans like: "Come to see us if you have a Technology issue! We are the MacGivers of the Science and you will never be alone", the majority of its SME partners did come to see ONERA addressing their technology issues. They had generally already identified a business-growing opportunity while calling on ONERA's TTO and they were looking for missing competencies in their company. We describe this as a Market-Pull approach. Technology-Push instead occurs when ONERA's TTO promotes a technology newly developed within ONERA and negotiates a license with an interested SME (or start-up).

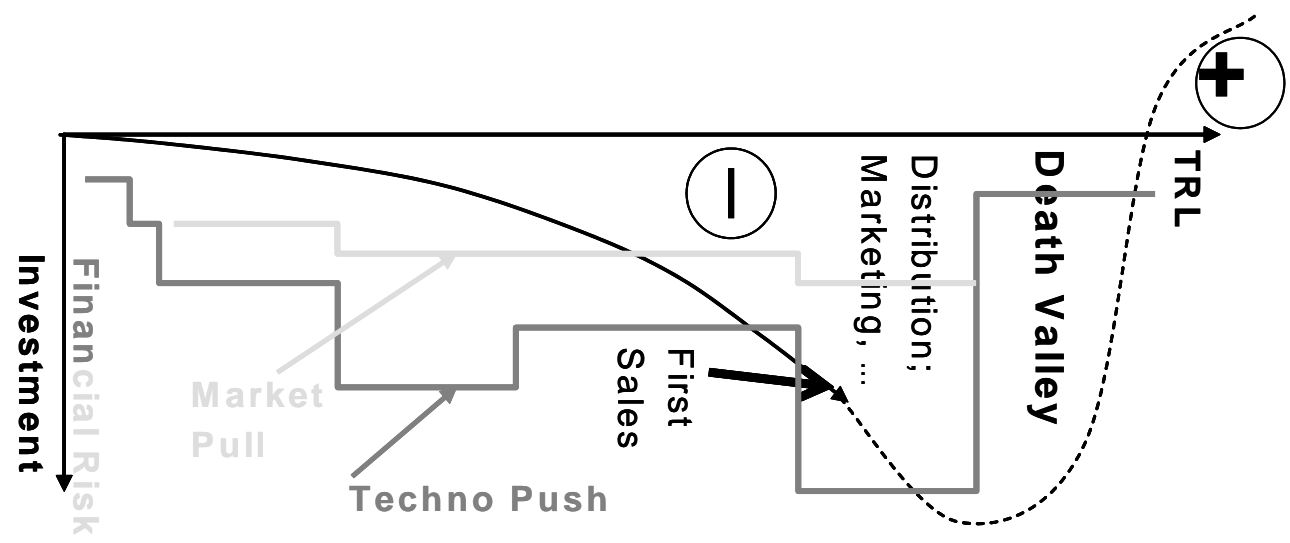

\section{Figure 4: Risk curves related to the Technology Development Investment curve}

Based on our observations and royalties return, Market-Pull projects have until now been the more successful. Accordingly, we propose our analysis of these results. In Figure 4, the risk curve for a technology-push approach is given by the continuous stepped line, while the dotted line shows a case of the market-pull approach. We can observe that both exhibit a high level of risk while investing in operational technology demonstrations and above all in launching New Products (goods and services) into the market. Nevertheless, we remain confident about our implicit assertion in Figure 3 that, throughout the cycle, the risk levels are lower in the MarketPull approach than with Technology-Push.

This lower risk exposure is induced at each stage by the belief that the SME partner has already identified a market and already possesses a structured production chain (including a supply chain). These considerations act as drivers throughout the technology collaborative development process, raising the company's rating on the TRL scale, thus reducing its risks and costs. The Market-Pull approach also seems to accelerate this technology development process; thereby accentuating the dynamic capabilities that the firm is able to parade.

We further adopted a hybrid strategy for ONERA while working with SMEs. Indeed even if the market-pull approach seems to be less risky and sooner beneficial, and even if it is producing incremental and often radical innovations by changing the domain for the adopted aerospace technology, we do believe that some technology-push activity will continue to be important for eventually nurturing disruptive innovations in ONERA's core business domain. Another important reason in continuing to promote technology-push activities through its TTO is the 
higher degree of motivation provided to its scientists while promoting their newly developed technologies.

This hybrid strategy places the agents of the innovation system in a cooperative network generating newly created value through a process of technology transfer.

\section{II.3 - ONERA-SME partnership innovative strategy}

The ONERA-SME technology transfer process cannot be analyzed without taking account of the relationships of the two players with their own reference frames, in terms of evaluation and sectoral/territorial regulations, in the sense of Granovetter (1985). These are mechanisms that are external to the simple ONERA-SME relationship which must intervene and accompany this dual relationship throughout the entire collaborative project, and some of the collaborative tools proposed take them into account.

\section{II.3.1 - Collaborative tools and their development}

Initially, an analysis of the role of each player during the innovation process is proposed and even, albeit in a more restrictive way, in the technology transfer phase. As mentioned above, the activity of the public R\&D laboratories in France involves, structurally, TRL levels lower than levels 3-4, corresponding to the laboratory prototype stage. Only a few basic ideas conceived by the researchers attain this level of technological maturity and even fewer cross levels 3-4 to go on to levels 6-7, corresponding to the demonstrator in operational conditions or a product. This is because the development of technological demonstrators is no longer part of the mission given to public research in France, a situation that is actually even worse for products.

If, generically, during the TRL 1 level (basic research) and TRL 2 level (applied research), 1000 original ideas finish up numbering 100 (via the personal filter of each researcher leading him or her to retain only one idea for every ten that he or she may have), are then cut down from 100 to 10 (by discussions with his or her 'close' circle of colleagues), and finally slimmed down from 10 to 2 or 3 by debates with the line management and/or decision committees, it will be interesting to see how these 2 or 3 results from various projects can cross level TRL 2 to arrive at levels 3-4 of prototyping.

\section{II.3.2 - Asymmetries in technology transfer relations and collaborative tools}

It can be seen that the research activities in TRL 1 and 2 are really mostly by the research laboratories because few SMEs are able to conduct their own research at these low TRL levels. Most innovating SMEs (apart from those that are really small labs in their own right) invest more in $R \& D$ activities after demonstrating technological feasibility, because their ultimate mission is to sell products successfully, with an economic logic of seeking profits.

So, what can be done with a technology that reaches a research laboratory at level TRL 2? At this stage, a laboratory prototype can be shown to be feasible by simulation and/or the existence of certain elementary components with strong chances of success. Who must now invest in the development of this prototype and on which criteria should the decision be based?

It seems obvious that at this stage the laboratory should consult the possible bearing vectors in the market: large groups and SMEs. If the technology developed corresponds to a strategic axis of development in a large group, quite naturally the latter will be interested in the appropriation of this technology or, at least, in a competitiveness comparison with other solutions. The partnership process that would take place between the laboratory and this large group is not the subject of this analysis. 
The case that interests us is that in which an existing SME is interested in this technology, whatever its branch of industry. When no SME or large group expresses interest in the use of the new technology then there only remains the option of launching a start-up partner, in the case of a 'disruptive' technology with high development risks and market potential, to be confirmed by market research; otherwise the development has to be abandoned.

\section{II.3.3 - Technological asymmetry and Risk asymmetry}

On the two assumptions, both for an SME and for a start-up partner, the problem of maturing technology up to the TRL 3-4 levels remains the same. It will be very difficult to get the SME or the start-up partner to finance this maturation. All this is related to the structural problem of financing developments in France but also to the lack of leading-edge scientific skills within the SME, allowing dialog with researchers and the appropriation of technology under the TRL 3-4. An asymmetry of technological capacity is revealed here and an asymmetry of the risk (financial) between the two participants: the public research laboratory and the small company.

Indeed, 95\% of French SMEs are small companies with less than 50 employees (INSEE, 2008). The development and demonstration of a new technology based on emerging technology from aerospace together research cost at least around one million euros (according to our own experience in the relationships with our SME partners), without counting the launching and development costs of the product line. However, most of the innovation assistance available in France is limited to $50 \%$ of the global amount (see Oseo, 2008, on refundable advances). This means that an SME that undertakes the development of a new product for a breakthrough innovation must assume half of the costs itself. For an SME with twenty people, $€ 500 \mathrm{~K}$ may well represent $25 \%$ of its annual wage bill.

Here, a significant risk asymmetry is to be noted between the SME and ONERA because possible failure could mean a cessation of activities for the former. The same amount represents the cost of four ONERA researchers - in other words, of its far higher R\&D 'capacity'. Moreover, financial risk exists and is not negligible, especially in the EPIC culture, where we will see later that the scientists involved in the technology transfer relationship are very little aware of the risk for ONERA compared to the degree of the risk assumed by the SME. Other authors (e.g. Serfati, 2008) have also stressed the importance of social relationships (including cultural relationships) in the innovation process. This difference in mentality was identified without any ambiguity in the collaborations undertaken by ONERA with various SMEs.

A mechanism to try to solve this technological maturation and asymmetry problem has been developed at ONERA: the shared risk development contract. This type of contract was developed and signed, for the first time in France, between an EPIC and a business firm.

For this phase of technology maturation ranging between TRL 2 and TRLs 3-4, the risk is still too great to be borne entirely by an SME as long as the technological proof, at least in the laboratory, as well as a complete comprehension of the technology, have not been achieved. It seemed right to us that ONERA, as a creator of technology, should be able to join future industrial and commercial owners in order to reduce the risks, and share the possible future benefits. The partnership is based on a technical and economic analysis of various phases of the development and on a Business Plan detailing the market prospects and investment returns on the new product. Based on this, ONERA can decide to assume part or all of the costs, within the framework of the co-development, the refunding of which, with profit-sharing based on business success, will take place or not, depending on the prospects for the use of the product.

The negotiation of the percentage allocated to sales, so as to cover ONERA's costs and its exposure to risk, is conducted according to criteria allowing the development of the company but also bearing in mind the fact that ONERA must make a positive return on all the operations of this kind. Thus, this contract is not a sort of license, nor a subsidy. The principles on which this 
contract is based are those of a service provided by ONERA on the basis of a determinable (though undetermined) price with payments deferred in time, negotiated between the parties on the basis of later sales and for a length of time agreed upon as part of the same negotiation.

This type of contract proves to be a very good tool, both financially but also technically, for collaboration with co-design in mind, for the development of a new product, a logic equivalent to that described by Cowan (2003). This tool means two parties can together cross, within the meaning of Aoki's theory (Aoki, 2000), based on a Nash equilibrium (Nash, 1950), a possible financial and technological comprehension barrier that may otherwise induce blocking.

In addition to compensating for risk and technological asymmetries between the two parties, this contract has also subsequently proved to be a good tool for reducing transactional information asymmetries (Akerlof, 1970; Stiglitz \& Weiss, 1992) between the start-up partner and its investors. Indeed, at the time of the phase of 'due diligence' between the creators of the start-up partners and the Business Angels, the shared risk development contract, signed with ONERA, yields paramount information on both the product and the target market, and on the technological developments and their costs.

This last year, at ONERA, three contracts of this type were signed with various commercial companies and four others are in advanced negotiations. Two of these companies have succeeded in raising funds from investors.

\section{II.3.3.1 - Institutional asymmetry (mentality and behavior)}

The shared risk development contract is a collaborative tool that compensates for technological and risk asymmetries. Such a tool also compensates indirectly for a very important asymmetry in the relation between the transmitter and the receiver in the process of technology transfer, institutional asymmetry, a term introduced here analogously with the terminology of institutional economy, within the meaning of "thought and action practices" by Veblen (1899) of "shared mental models" and "belief structures that intervene as formal and abstract constraints to structure human interactions" by North (1994).

This asymmetry has been thoroughly analyzed because it can sometimes induce a more significant form of blocking in a dual relationship: cultural blocking. The word 'institutional' must be understood as a sum of the rules, but also in its abstract aspect as a sum of beliefs, prejudices, instincts and behaviors: "Institutions are dominant thought and action practices" (Veblen, 1899). All these elements are generated historically, according to the way in which the actions are carried out and are assessed, but more especially through received education.

Historically, applied research in France is really quite concentrated in national research centers specialized in a particular field (IFP, CEA, ONERA, Inrets, Inra, Inria, etc.). The universities have generally not been perceived as possible players in applied R\&D. The proof is that before the Allegre Law in 1999, very few universities in France had a research result utilization service, and even these, before the Pecresse Law in 2007, did not have that complete autonomy which would allow them, among other things, to have a close relationship with the economic world.

The Summary report of assessment of the universities of the wave B (AERES) made an observation which alludes to this: “... Socio-economic milieus.... their influence on the policies and strategies of the establishments are generally weak, because of their lower level of involvement in the councils of the establishments".

The utilization activity developed since the Allegre law seems itself to be directed toward research contractualization and expertise-based services, but hardly at all in the field of technology transfer. The following can be read in the same report: "Utilization - this is a declared objective in all establishment strategies. Management structures (service, SAIC, subsidiary companies, direction, etc.) exist in the majority of these, for industrial contracts and service 
performance. On the other hand, the management of patents and licenses and, generally, of intellectual property, financially costly and requiring specialized skills, is accessible to these establishments with great difficulty. A really effective utilization policy would require the creation of consortia within a regional or even national framework to reach the critical size necessary for effectiveness."

Leaving, in passing, to the reader the appreciation of the desirable ways of improvement, as they are recommended in this quotation, we should mention that nowhere in this report is a mechanism suggested for listening to the needs for development being expressed by the markets.

In the Guide of the expert - Wave C of May 2008 of the same Agency (AERES) we can find positive developments going in the direction, in terms of the evaluation criteria, of taking into account activities around the utilization of research within the organizations being assessed.

It is explicitly requested that the number of patents, the number of declarations of inventions, the cost of the patents, as well as the revenue generated by these, all be taken into account but, above all, the number of licenses. However, other fundamental indicators are lacking for a complete measurement of utilization activity, such as the revenue from possible capital shares held in the companies profiting from technology transfer, the evolution of the value of these companies, or the number of jobs created on the basis of these technologies.

This, coupled with consideration of a criterion on the patentable technology detection activity within the establishment, but not of one on the capacity of listening to the market needs, or the capacity to carry out market research, will generate a culture of technology push instead of a market driven culture, generally recognized (among discussions at T2S or AUTM Annual Meetings) as a better generator of innovation.

Thus, the economic culture of the researchers is built throughout their career by indicators on the basis of which they are assessed, the most important indicator being recognition by peers, gained mainly through publications by the researcher according to panel reviews. However, while publication circulates research results efficiently, without an adequate preliminary control it is contrary to the utilization mission of national industry and likely to reveal unprotected knowhow.

In this same guide, the number of A and A+ type publishers is an important criterion in assessing establishments. The identification criteria of these authors include international patent deposits but do not stress those that were granted a license. Also, protection of the results is confused with their utilization and as a result it is likely that a great number of patents of no importance may be obtained because they do not contain any criterion bearing on their economic impact. It would undoubtedly be necessary to optimize the respective weights of a license, the incomes obtained with the latter, the patent and the publication.

There is a legitimate question to be asked here: when does a license generating significant income have the same weight as (or even a greater weight than) an article published in Nature? There is indeed no antagonism between a patent and the publication of results from their source, only a priority on the submitting of the patent is to be respected. If a license counted for three traditional patents or nine publications ... could this induce a change of mentality within the public research community?

Moreover, this mentality is the subject of an unambiguous analysis in this same report concerning the governorship of research establishments: "in multiple-field establishments, faculty-centered organization remains very vigorous. In certain recent universities, it is an acknowledged will. The evolution of mentalities and practices is thus very slow..."

The recent "Carnot Label" awarded to research establishments with partner research activities with industry (Carnot Law) has made it possible to evaluate the co-operation between industry and public research in France. Thus, the 33 Carnot Institutes, accounting for only $12 \%$ of the 
French public R\&D manpower, generate nearly $50 \%$ of the research contracts with industry, for a total budget of $€ 450 \mathrm{M}$, representing merely $1 / 3$ of their annual consolidated budget. The share of this budget with the SME is however insignificant.

So could a researcher become convinced that the utilization of research results is a noble aspect of his or her activity? This mentality, based rather on the "craftsman instinct" within the meaning of Veblen (1914), induces a strong asymmetry in the relationship between a researcher and an SME director, who will rather act according to a "predator instinct" from the "cultural" point of view, during their interaction for a technology transfer. This asymmetry may be strong at the beginning of the relationship, and can be compensated for gradually if a favorable environment is created to help the relationship to evolve from a transactional framework towards that of cooperation.

Now that this institutional asymmetry concept has been introduced, we can see that the technological capacity asymmetry triggers collaboration between both participants and that the compensation of information and institutional asymmetries is the facilitator because, at the beginning of their relationship, both parties face problems arising at the same time from the lack of technical information but also from the capacity to implement these once they are available (for example, it is not enough to read a patent to be able to manufacture a new product).

The shared risk development contract is one of the mechanisms allowing the compensation of institutional, technological and financial risk asymmetries, during the the integration of researchers into the SME, when a technology transfer towards the SME takes place.

This evolution results from acknowledging the failure of the existing spin-off policies of the public research establishments, whether in France or elsewhere in Europe. The great scarcity of researcher spin-offs is a logical consequence of the natural differences in skills necessary as between the enterprise world and that of research. Success in the creation of a company depends not only on the quality of technology, but particularly on that of the management team, and on financial and operational resources, in order to control marketing, commercial, financial, industrial and productive components, making it possible to move, in a limited period of time, from a good technology to a business success. The goal of the Charter revision, toward integration of the researcher wishing to "spin-off" into an existing structure, is thus to support the meeting, within a pre-existent framework: that of the SMEs, of these components of success so as to reduce the risks, for both the researcher and the SME, and for ONERA as well.

The departure of the researcher to the SME wishing to accommodate him or her, with the transfer of a technology in which he or she is an expert, takes place under conditions that are at the same time safe and incentivizing; in particular, the traditional conditions: the possibility of returning to ONERA during the first three years, financial aid, and the financing of training to reinforce the necessary skills for his or her new mission.

The main point is however the condition of opening the SME capital to the researcher in order to position him or her as an "entrepreneur" on the same level as his or her new partners (at least 5\% for a small company; flexible for an average-sized company). This makes development of "cultural" positioning possible for the spin-off researcher, and a clear confirmation of the interest of the receiving SME for the new business that the researcher will contribute to develop and manage within it.

\section{II.3.3.2 - ONERA-SME Technology Charter}

In order to give a more general framework for these relations, to gather the collaborative tools, to define the principles of the expected collaboration with the SME, and to ensure this collaboration policy can be maintained for the foreseeable future, ONERA made the strategic choice of setting up an ONERA-SME partner technology Charter. 
This Charter itself had to go beyond the simple problems of technology transfer and explore all the collaboration possibilities between ONERA and the small business world. It represents a moral engagement of the two parties, based on the principles and methods of collaboration and the values governing them. It also means the two parties wishing to collaborate can be on active watch, reciprocally validating their collaboration potential, and be able to start a collaborative project at the earliest opportunity.

This Charter is fully positioned as an institutional collaborative tool, within the meaning of Aoki's theory (Aoki, 2000). The two participants do more than give themselves the means by which to develop together because they are both on active technological watch in their respective markets, identifying opportunities for joint projects.

It relies on simple and tested principles of 'win-win' and 'give-give', providing benefits for each participant, as summarized below:

i) Mutual benefits

a) Technological ${ }^{10}$ benefits and opportunities for an SME

Such partnerships make it possible for the SME to have access to R\&D contracts in partnership with ONERA, to scientific expertise across the entire civil and defense aerospace field, and to technology by means of licenses, simulations, calculations, testing tools, simulation tools or software runs ${ }^{11}$ and technological watches.

These can reinforce its competitive advantages from accumulating competencies out of the framework of R\&D contracts, by proposing solutions that involve a stronger scientific added valuethanks to the contribution of ONERA, both from becoming first phases of technology transfer. To allow later developments, up to the marketing of products, ONERA has adapted its Spin-off Charter, as another collaboration tool, in order to support

integrated into experimental projectsand technological demonstrations, and by allowing more competitive serviceswith a better adjusted division of the types of servicesprovided by ONERA and the SME.

They permit giving access to marketsand customers that would be difficult for anSME to reach alone, since the latter will now have the benefit of the "ONERA Partner" label to present to large institutional and industrial accounts, thereby dodging some of the weaknesses of being small through taking part in the cooperation project.

The SME can also profit from the outcome of developments in contracts with ONERAfor progressing towards commercial use ofnew products in its markets.

\section{b) Benefits and opportunities for ONERA}

This partnership reinforces the competitive advantages of ONERAwithin the framework of R\&D contracts, achieving this in various ways:

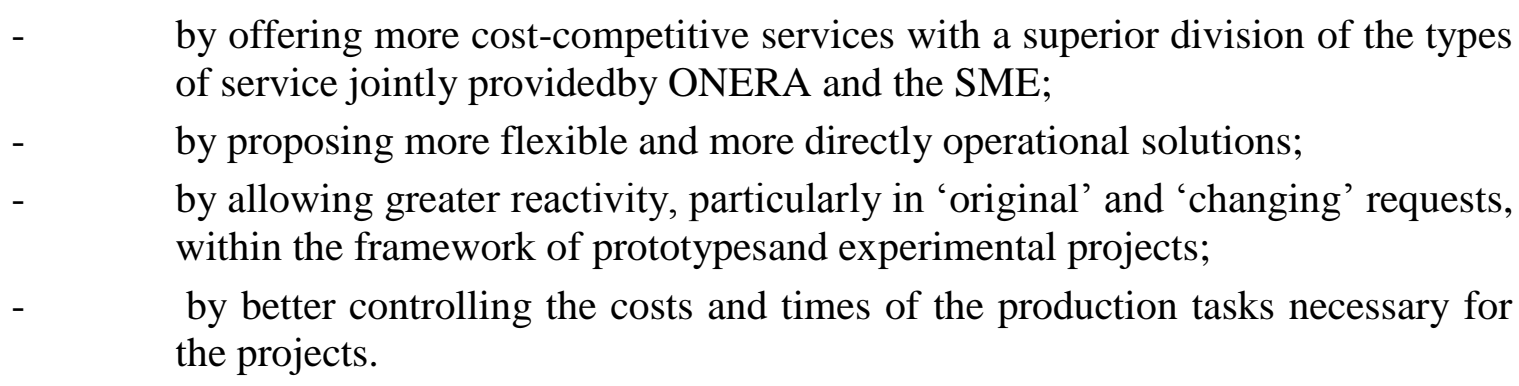

The partnership offers access to customers/end-usersnot directly accessible by ONERA,supports mutual enrichment and emulationbetween the teams of ONERA and the SME, allows ONERA to

\footnotetext{
${ }^{10}$ For SMEs that involve themselves in the development of technologies in addition to their use.

${ }^{11}$ Launching the computations on ONERA's super-computers
} 
be proactive and play a driving rolein the industrial field,and offers more dynamic potential outletsfor utilizing the research results, particularly for its technology transfers.

\section{ii) Types of partnership}

Several partnership modes can be implemented to carry out this project, such as partnerships in R\&D contracts, the expertise and use of ONERA methods, shared risk development contracts, technology transfer/utilization of ONERA know-how; this goes as far as the detachment of researchersand/or their spin-off into the SME.

\section{iii) Profile of targeted SMEs}

The desirable profile fortargeted SMEs must allow fast self-identificationby the SME of its own capacity to enter into a partnership framework with ONERA by:

- $\quad$ having a production activity or technology service;

- $\quad$ working in a field that can benefit from the outcomeof ONERA's research;

- $\quad$ devoting - or having an objective to devote - at least $8 \%$ of its Turnover to $\mathrm{R} \& \mathrm{D}$ activities (this minimum can be modulated according to the size of the company)

- $\quad$ having financial viability;

- $\quad$ satisfying the SME criteria of the European Union;

- $\quad$ adhering to the values of the ONERA-SME Charter.

\section{iv) The "values"}

This Charter is primarily a moral engagement between the parties, resting in particular ona common vision of the business rules of the partnership:

- innovation based on scientific and technical excellence: scientific and technical excellence is one of the basic elements identified by the SME for the development of its innovating productsand services. This excellence is based on an internal R\&D policy at the SME, as well as on external contributions, including among others those of ONERA;

- a quest for performance: the concretization and perpetuation of success are guaranteed by a permanent search by the SME for improved economic performance, within the framework of the development and marketing of its goods and services;

- constructive competition and fair-play: in the event of competition betweenSMEs on contractual or utilization activities, this will only proceed on the basis of technical and economic criteria, seeking performance and in a spirit offair-play between them, respecting the customer and/or ONERA. In particular, it would be a case of forbidding higher technical or economic bidslikely to lead to an unidentified risk for the customerand/or ONERA.In the event of competition with ONERA, the rules of free competition apply; a reciprocal tendering procedurecould be considered to assess a possible cooperative venture;

- independence: eachSME preserves its independence; the network may be mobilized in defense of shared interests, but - barring exceptions - cannot be used to support private interests;

- commercial ethics: the operation of the project shall be according to recognized commercial rules of ethics, in particular to exclude any private interestsituation between ONERA and SME researchers that may generate specific conflicts.

\section{RESULTS}

To date, 87 SMEs have signed theONERA-SME Charter and more than 40 licensing agreements, know-how communication agreements orshared riskdevelopment contracts are currently running, with various industrial partners in a variety of fields. Of these, 28 were signed over the past four 
years, corresponding to the new development policy, while the remainder (12) represent the historical 'heritage' of the old ONERA development policy.

Table 2: ONERA-linked SME partners (selection only)

\begin{tabular}{|c|c|c|}
\hline Partner & Application & Type of collaboration \\
\hline Leosphere & Wind lidar & $\begin{array}{l}\text { License, common R\&D and } \\
\text { spin-off contract }\end{array}$ \\
\hline Oktal-SE & $\begin{array}{l}\text { Electromagnetic environment } \\
\text { simulation }\end{array}$ & $\begin{array}{l}\text { Software licenses } \\
\text { andcommon R\&D contracts. }\end{array}$ \\
\hline Phasics & Laser interferometer & $\begin{array}{l}\text { License and ONERA post- } \\
\text { graduate student recruiting }\end{array}$ \\
\hline Protip & $\begin{array}{l}\text { Biomedical prosthesis containing } \\
\text { porous Titanium }\end{array}$ & $\begin{array}{l}\text { License and shared } \\
\text { riskdevelopment contract }\end{array}$ \\
\hline Ixsea & Inertial navigation & License \\
\hline Sirehna & Drones and gliders & $\begin{array}{l}\text { Common R\&D contract and } \\
\text { software license in fluids }\end{array}$ \\
\hline Satimo & Medical imagery & $\begin{array}{l}\text { Common development } \\
\text { contract and license }\end{array}$ \\
\hline Isitek & Medical supervision in residence & License on sensors \\
\hline Microcertec & US machining of ceramics & License \\
\hline Fogale-nanotech & Capacitive sensors & License \\
\hline Andheo & Fluid mechanics and energetic & $\begin{array}{l}\text { Software license and } \\
\text { common R\&D contracts }\end{array}$ \\
\hline Sofratest & Flow measuring & License \\
\hline C3EM & $\begin{array}{l}\text { Fissure monitor and experimental data } \\
\text { acquisition station in wind tunnels }\end{array}$ & $\begin{array}{l}\text { License, common R\&D } \\
\text { contracts }\end{array}$ \\
\hline Secapem & $\begin{array}{l}\text { Real-time shot acquisition and } \\
\text { validation system }\end{array}$ & $\begin{array}{l}\text { R \& D contract and software } \\
\text { license considered }\end{array}$ \\
\hline Mapaero & Pressure-sensitive paint & $\begin{array}{l}\text { Know-how communication } \\
\text { agreement }\end{array}$ \\
\hline Michalex & $\begin{array}{l}\text { Micro-indentation at very high } \\
\text { temperatures }\end{array}$ & $\begin{array}{l}\text { License andshared risk } \\
\text { development contract }\end{array}$ \\
\hline ACV Aeroservice & Quiet green aircraft & $\begin{array}{l}\mathrm{R} \& \mathrm{D} \text { contract and shared } \\
\text { riskdevelopment contract } \\
\text { envisaged }\end{array}$ \\
\hline Nheolis & New type of wind power station & $\begin{array}{l}\text { Shared riskdevelopment } \\
\text { contract }\end{array}$ \\
\hline Keopsys & Laser & License \\
\hline
\end{tabular}

Following the successful implementation of the new collaborative tools during this period, the number of collaboration agreements signed went from one to more than ten agreements per year. The number of spin-offs went from one spin-off every five years to one spin-off on average per year.Fifteen new proposals for common $R \& D$ contracts also came to light during this last period.

Table 2 provides a selection of the partnerships withSMEs, this selection having been made on the basis of their diversity. 
A first experience feedback is nowavailable with the results of an investigation conducted with the SME partners.A questionnaire concerning the ONERA-SME collaboration was addressed to them, and 42 of the 68 SME partners, at that time, answered it.Of these 42 SMEs, more than $80 \%$ have become partners of ONERA over the last four years.

This questionnaire thus made it possible to confirm the first concrete results, in particular the creation of 170 jobs, at these 42 SMEs that answered the questionnaire, since the beginning of their relationship with ONERA. Among these, 104 jobs can be ascribed directly to the new activities developed bySMEs based on ONERA technology. The funds raised by the partner SMEs amount, to date, to more than $€ 20$ million.

One of the particularly importantquestions with regard to the confirmation of the role of collaborative toolsin the reduction of information asymmetry between theSME and other economic participants was: "To what extent has your relationship with ONERA influenced your development?" It revealed that half of those who answered confirmed having an image or credibility benefit thanks to the partnership. Such reputational effects represent a case of dynamic appropriability that seems well worth pursuing in the near future.

With regard to the development of the relationship with ONERA, half of those who answered would like to reinforce their direct relationship with ONERAresearchers (either in the form of direct expertise, or within the framework of a spin-off of the researcher into their team). Half of those who answered also wish to be better informed about developments in hand and the strategy of ONERA. The two indicators reveal a need to compensate the technological asymmetries and reduce the informationasymmetries that still exist between the SMEs and ONERA.

The answers to this questionnaire and the knowledge of the operating rules of ONERA have led to proposals for new mechanisms, mostly within ONERA, which could compensate for a number of the asymmetries between the SMEs and the Office even more. Thus, a need for the following aspects was identified:

- the development of a specific strategy whereby severalSME partners, together withONERA, develop technological demonstrators of the 'systemic' type; the consortium thus constituted no longer adopting a management characteristic of a sequential innovation process but horizontal management (Rothwell, 1992) more suited to multiplefield and multifunctional teams;

- the development of anSME partner skill catalogue, to be distributed within ONERAto the research teams;

- the periodic organization of joint events between ONERA and the SME, to which other participants such as customers would be invited, and the various innovation assistance structures;

- the creation of a network of experts, with adequate training, to provide a single interface with the SME;

- the possibility of conducting market research;

- the development of joint ONERA-SME laboratoriesfor maturing technologies.

\section{III.2 - The common technological maturinglaboratory as a collaboration tool}

In addition to other collaborative tools, it seems appropriate, in the case of complex projects requiring a technological maturation betweenTRL 2 and TRLs 3-4, for it to be possible for this to take place in the public laboratory's own maturationlab, a joint arrangement for which future technological developments are managed cooperatively with the SME partners. This laboratory would accommodate mixed teamscomposed of SME (or start-up) employees and researchers. The personnel costs would have to be borne by each party for its own staff. Mechanisms external to the SME-ONERArelationship, making it possible to ensure up to $80 \%$ of the wages of a professor(or researcher) recruited by an SME, have been put in place recently at Oséo. 
The question of the financing of this Common Technological Maturation laboratory could also be resolved by making use of the additional Carnot contributions(under the Carnot Law) that the Institutes that are members of the Carnot Institute Association receive, to boost their scientific and technological resourceswithin the framework of their partnership policy. This is because one of the goals of the Carnot label,amongst others, is to support technology transfers. It remains a fact that no technological maturationshould be undertaken without preliminary market research, with product/market cross-referencing as obligatory.

The Common Technological Maturation laboratory would also function as a new collaborative tool, facilitating the compensation and reduction of technological asymmetries(in its institutional aspect and in terms of the lack of information) between the two participants in thetechnology transfer but also as compensation for the risk asymmetry.

\section{CONCLUSIONS}

This study has attempted to blend the theoretical demands imposed by approaches such as those relating to innovation studies (the viewpoint of dynamic and interactive capabilities), or the economics of information (highlighting asymmetries) especially as SMEs prevail on the side of customers for the technological competencies supplied in such circumstances. The first results show a series of development successes for innovativeproducts based on technologies created by ONERA, and this in a great variety of sectors viewed at the meso level, going from biomedical prostheses to the wind power market.

The study, as far as it goes casts some light on the old and still largely unresolved question of how largely tacit knowledge - locked away inside a large and probably discreet organization, and representing its penrosian slack (Penrose, 1959; Brusoni et al., 2001) or 'excess knowledge capacity' - can recirculate around its coterie of knowledge-hungry SMEs. Moreover it can do so effectively enough to become not just their new competencies but their new capabilities.Basically, to do so involves close relationships to weaken all the forms of asymmetry, built around constant interchange of personnel as well as ideas and information, etc.

This research also contributes to Stiglitz's “information asymmetry theory" by acknowledging the need to reduce and/or compensate for different asymmetries while carrying on a cooperative process like technology transfer which has impacts on all levels: direct impact on the agents (micro), on the regulators (regions and sectors - meso), and on economic growth (macro).

\section{IV.1 - The impact at the micro level}

As for any form of transaction, in a technology transfer process, the parties involved are informationally asymmetric. The new SME policy at ONERA has in addition given serious consideration to other forms of asymmetries characterizing the technology transfer and partnership research between a public research organization and an SME in France: technological capacity asymmetries,institutional asymmetries and those of financial risk.

The collaborative tools deployed at ONERA within the frameworkof its new development policy, the shared risk development contract, the ONERA-SME Charter and the Spin-offCharter are mechanisms designed and implemented to ensure the reduction of the informationasymmetries and compensation for other asymmetries between ONERA and its partners. The Common Technological MaturationLaboratory is another proposal for a collaborative tool similar to those already in place.

The relationship established between ONERA and an SME is perceived more as a cooperative relationship for a co-development rather than as a simple studyservice (i.e. just transactional). This relationship imposescompensation for financial risk and technological capacityasymmetries in addition to institutional(mentality) asymmetries and the reduction of information asymmetries 
between the two parties. Attention is thus drawn to the importance of the "issues of confidence and interest"(Cowan et al., 2003) in a technology transfer relationshipwith regard to the questions of opportunity and uncertainties in a product/service salesrelationship (in theFord sense). Each partner must, to some extent, learn and understand the culture of the other, without losing its own, in order to understand better and more generally to do what is necessary in order to balance the various asymmetries.

Moreover, the ONERA-SMECharter and the shared risk development contracts ${ }^{12}$ have also proven to be very effective tools in the reduction of information asymmetries between theSME (or the start-up partners) and other socio-economic players (investors, competitiveness centers, etc.).

At ONERA, the cultural change taking place amongst the researchers involved in a relationship with anSME can be observed. Their contractual liability is reinforced by a better awareness of what is at stake, which the successful transfer of their know-how to theSME represents. They adopt the "predatory instinct"(Veblen, 1914) of an entrepreneur, interested intransfer opportunities for their technology outside the aerospace field. The implemented tools operate as relational facilitators in the relationship betweenONERAand the SME but also in the internal relationship within ONERAbetween the scientists and the supportstructures for utilization.

The success of the operation ofcollaborative tools changes the internal operationrules specific to ONERA and allows proposing new internal mechanisms,such as the creation of a network of experts as a single ONERA interfacewith the SMEs, and the future possibility of carrying out market research.The purpose of these mechanisms will be to increase still further the effectiveness of the partnering relationship with the SME.

\section{IV.2 - Impacts at the meso-economic level}

The first successes with the signing of the ONERA-SMECharter by more than 70 SMEs recognize and prove the significant role that ONERA can play as a source of innovations and also as a catalystfor a cluster of skills and multi-sector innovations. This is valid for all the regions where ONERA is represented, thus confirming the views of other authors (Etzkowitz, 1999; Florida \& Cohen, 1999).

ONERA's change of strategy in the choice of its customers, because of its opening to the world of the SME, has had an effect on the diffusion of its technologiesbeyond the aerospace field and especially on its positioning in other marketsectors as well as in its relationship with its customers. Having a study service relationship with a large industrial group, ONERA has now also given itself the opportunity of having a co-development relationship with the SME partners.

The intervention of ONERA in multi-sector innovations,on the basis of its research results in the aerospace field, puts the Office in competition with other traditional suppliers ofresearch, in each of their specific fields. This has an impact on the 'forms of competition' (costs, quality, speed of development) and ONERA could thus find itself in an advantageous positiondue to its multidisciplinary skills.

The new form of "multi-sector innovation" competition, inducedby the new ONERA-SME policy, could prove to be important from the point of view of access to public funds. Thus

\footnotetext{
${ }^{12}$ The shared risk development contract has been developed by the ONERA DCV team during the last 5 years. The authors of this article who took part in developing this tool wish especially to thank Corinne Le Hong for her contribution in updating the Risk Sharing Co-Development contract and to Frédéric Lamy for his contribution in updating the same contract, but also to the entire team (led by Mihel Lambert) who are nowadays continuing to capitalize upon and develop the concept with SME partners.
} 
ONERA, in partnership with a suitable cluster of SME partners, is able to bid for public programs to build technological demonstrators. In some of these programs, this could generate fair-play competition with its own strategic partnersamong the large aerospace industry groups.

ONERA's new policy of development with SMEsoffers a solution to the problemencountered in a general way by clusters of companies, of the competitiveness center type, which are based on the effects of agglomerationand of specialization(Weber, 1909/1929). This cluster model has proved risky for long-term developmentdue to exaggerated territorial specializationand the lack of job diversification, skills and sectors in the region, which could thus become a disadvantaged "small world" (Watts \& Strogarz, 1998).

The positive effects of this new policy at the territorial level have been confirmed for the effects of complementarity and the interactions thus generatedbetween various SMEs (Zimmermann, 2002), encouraging them to work in complementary sectors, not necessarily belonging to the regional competitiveness centers; this has been in order to develop innovative solutionsin their sectors based on the high technology licensed by ONERA, a form of technology originally developed for the aerospace sector but potentially adaptable to the needs of low and mediumtech sectors (von Tunzelmann \& Acha, 2005).

One of the results of the practical application of the new ONERA-SME policyis that ONERA became a "distant source"(Maskell et al., 2005) of new ideas and expertise for other competitiveness centers outside the aerospace field. Thus, ONERA's SME partners and members of these so-called competitiveness centers no longer depend only on internal interactionsspecific to the center that they are members of in order to have access to R\&D resources, but also benefit in their innovation work from skills that are external, in the geographical and sector sense.This reasoning has proved to be valid also for the case of geographically isolated SMEs that encounter difficulties in becoming members of the centers of another area, the partnership with ONERA allowing them an important access to R\&D skills.

As a transition to the macro-economic level, an important perspective could directly impact the development policies of regionally specialized clusters, as with the national strategies for innovation. The R\&D laboratories will adapt their behavior by intensively using asymmetries compensation/reduction mechanisms in their relationship with the regionally specialized SMEs but also with other SMEs, not regional or acting in other domains. Thus, the regionally specialized clusters (supposing there is more than one present in the same region) will be interconnected through direct collaborations occurring between some of their "provider (R\&D labs)" and technology "consumer (technology adopter SMEs)" members. They will also be interconnected with other non-regional clusters. These types of interactions, driven through either Market-Pull or Technology-Push (or Hybrid) approaches, will exchange technology inside and outside their related clusters, with no more monitoring by Clusters Authorities. To upgrade this type of possible multiple embedded innovative system, mainly based on technology transfer between providers and consumers of technology, we consider that smart grids models could be an appropriate approach (Paun, 2010).

\section{IV.3 - Impact at the macro-economic level}

The relationships that the SME partners have developed with ONERA allow changes towards sector-based operating rules specific to the innovation assistance structures or to regional development, in relation to professional networks, in the sense of "cumulative causality" (Veblen, 1914) or of "recursive causality" (Morin, 1990). Thus, it has been observed that some of ONERA's SME partners, especially the decisional committees of this type of structure (competitiveness centers, trade associations), proselytize for this new type oftool to collaborate in public research with other members of such committees. 
Other national structures grouping various innovation players actively examine some of the collaborative tools developed within the framework of the new SME policy of ONERA. These tools are often the subject of analysesby think tanks made up of these national structures,in order to exchange ideas regarding good practicesbetween their respective members.

The adoption and/or generalization, after the inherent adaptationsdue to the sector-based specificities of the various parts, of these collaborative tools by these other structures or networks could induce the same positive results as those obtained by ONERAand its SME partners, on innovation at a national scale.

Many authors have identified, in the various studies of the conditions and mechanisms of financial support for innovationand their impact on economic growth, that information asymmetry (Akerlof, 1970; Stiglitz \& Weiss, 1992) is one of the major factorsinfluencing the financial risk taken to generate innovations.

The ONERA-SME collaborative tools have shown how their role can lie in the reduction of this asymmetrybetween these SME (and start-up) partners and their respective investors. Indeed, the fund-raising required for the development of projects by the SMEs became much easier.The generalization of this type of tool will no doubt mean the constitution of a better Business Angels cultureand Venture Capital in France and, especially, the appearance of new investors due to the reduction in financial risk as a result of the reduction of information asymmetrybetween the SMEs (or start-up partners) and investors. As an example, the shared risk development contract, signed by start-up partners with ONERA, proved thereafter to be a facilitatordocument in the phase ofdue diligence between the start-up partner and its Business Angels.

\section{$\underline{\text { References }}$}

Allègre Law- Law no.99-587 of July 12th 1999 on innovation and research- NOR: MENX9800171L, JO of 13-07-1999, pp. 10396-10400.

Carnot Law - Programme Law no. 2006-450 of April 18th 2006 for research- NOR: MENX0500251L, JO of 19-04-2006, p. 5820, text no. 2.

Pécresse Law - Law no. 2007-1199 of August 10th 2007 relating to the freedoms and responsibilities of universities- NOR: ESRX0757893L, J.O. of 11/08/2007 text: no. 2 (page 13475).

AERES, 2008, Rapport de synthèse des évaluations des universités de la vague B (Summary report of the evaluations of the universities of the B-wave), http://www.aeres-evaluation.fr/ Rapport-d-evaluation-des-ecoles, 26 November.

Akerlof G.A., 1970, "The market for 'lemons': quality uncertainty and the market mechanism", Quarterly Journal of Economics, vol. 84, no. 3, pp. 488-500.

Aoki M., 2000, Information, Corporate Governance and Institutional Diversity: Competitiveness in Japan, the USA, and the Transition Economics, Oxford, Oxford University Press.

Brusoni S., Prencipe A., Pavitt K., 2001, "Knowledge specialization, organizational coupling, and the boundaries of the firm: why do firms know more than they make?" Administrative ScienceQuarterly, vol. 46, no. 4, pp. 597-621.

Carnot Institute Association, http://www.instituts-carnot.eu

Chandler, A.D.jr. 1977, The Visible Hand: the Managerial Revolution in American Business, Cambridge MA, Belknap Press.

Cohen W.M., Levinthal D.A., 1989, “Innovation and learning: the two faces of R\&D”, Economic Journal, vol. 99, pp. 569-596. 
Cowan R., Jonard N., Zimmermann J.-B., 2003, “Complémentarités cognitives et production de connaissances nouvelles, une analyse en termes de réseaux (Cognitive complementarities and production of new knowledge, an analysis in terms of networks)",Revue d'économie industrielle, La morphogenèse des réseaux, no.103.

Davies, A., Hobday, M., 2005, The Business of Projects: Managing Innovation in Complex Products and Systems, Cambridge, Cambridge University Press.

Etzkowitz H., 1999, "Bridging the gap: the evolution of industry-university links in the US", in L. Branscomb, F. Kodama and R. Florida (eds.), Industrializing Knowledge: University-Industry Linkages in Japan and United States, Cambridge, MIT Press.

Florida R., Cohen W., 1999, "Engine or infrastructure?: the university role in economic development" in L. Branscomb, F. Kodama and R. Florida (eds.), Industrializing Knowledge: University-Industry Linkages in Japan and United States, Cambridge, MIT Press.

Freeman C., 1987, Technology Policy and Economic Performance: Lessons from Japan, London, Pinter.

Golob E., 2006, "Capturing the regional economic benefits of university technology transfer: a case study", Journal of Technology Transfer, Vol. 31, No. 6, pp. 685-695.

Gorman, W. M. (1956), "A possible procedure for analysing quality differentials in the eggs market", Review of Economic Studies (1980), vol. 47, pp. 843-856.

Granovetter M., 1985, "Economic action and social structure: the problem of embeddedness", American Journal of Sociology, Vol. 91, No. 3, pp. 481-510; tr.fr.: Granovetter M., 2000, Le marché autrement, Paris, Sociologie économique, De Brouwer.

Hirschman A.O., 1958, The Strategy of Economic Development, New Haven, Yale University Press.

INSEE - http://www.insee.fr .

Lancaster K.J., 1966, “A new approach to consumer theory”, Journal of Political Economy, vol. 74, pp. 132-157.

Levy M., Jouyet J.-P., 2007, L'économie de l'immatériel (Economy of the Immaterial), report submitted to the Ministry for the Economy, Finances and Industry.

Lundvall B.-A., 1992, National Systems of Innovation: Towards a Theory of Innovation and Interactive Learning, London, Pinter.

Machlup F., 1959, "Statics and dynamics: kaleidoscopic words", in Essays in Economic Semantics, $2^{\text {nd }}$ edn. (ed. M. Perlman), Transaction Publrs, New Brunswick NJ, 1991, pp. 9-42.

Mankins J.C., 1995, Technology Readiness Levels, A White Paper, April 6, Advanced Concepts Office, Office of Space Access and Technology, NASA.

Maskell P, Bathelt H., Malmberg A., 2005, "Building global knowledge pipelines: the role of temporary clusters", World Development, vol. 33, no. 9, pp. 1715-1734.

Morin E., 1990, Science avec conscience (Science with a conscience), Paris, Fayard (1982), new modified edition.

Mouchnino N., Sautel O., 2007, "Coordination productive et enjeux concurrentiels au sein d'une industrie modulaire: l'exemple d'Airbus" ("Productive coordination and competing stakes within a modular industry: the example of Airbus"), Innovations, vol. 2007/1, no. 25, pp. 135-153.

Nash J.F., 1950, "Equilibrium points in n-person games", Proceedings of National Academy of Sciences, vol. 36, no. 1, pp. 48-49. 
Nelson R.R. (ed.), 1993, National Innovation Systems: A Comparative Analysis, New York, Oxford University Press.

North D., 1994, "Economic performance through time" (Nobel Lecture), American Economic Review, vol. 84, no. 3, pp. 359-368.

Paun F., 2010, "Spirit of Innovation IV”, Marseille, France

Paun, F., Richard, P, 2009, «Rôle des outils collaboratifs dans la réduction et la compensation des asymétries relatives au processus de transfert de technologie; étude de cas sur la nouvelle politique ONERA-PME » in «Le travail collaboratif. Une innovation générique », Marché etOrganisation, édition Harmattan.

Penrose, E.T., 1959, The Theory of the Growth of the Firm, Oxford: Blackwell; $4^{\text {th }}$ edn. (ed. C.N. Pitelis), Oxford, Oxford University Press, 2009.

Putnam R., with Leonardi R., Nanetti, R.Y., 1993, Making Democracy Work: Civic Traditions in Modern Italy, Princeton NJ, Princeton University Press.

Reinert E.S., 1994, "Catching-up from way behind: a Third World perspective on First World history", in J. Fagerberg, B. Verspagen and N. von Tunzelmann (eds.), The Dynamics of Technology, Trade, and Growth, Aldershot, Edward Elgar, pp. 168-197.

Rothwell R., 1992, "Developments towards the fifth generation model of innovation", Technology Analysis and Strategic Management, vol. 4, no. 1, pp. 73-75.

Scherer F.M., 1967, "Research and development resource allocation under rivalry", Quarterly Journal of Economics, vol. 81, no. 3, pp. 359-394.

Sen A.K., 1985, Commodities and Capabilities, North-Holland, Amsterdam.

Serfati C., 2008, "Le rôle de l'innovation de Défense dans le système national d'innovation de la France (The role of innovation in Defense in the French national innovation system)", Innovations, Cahiers d'économie de l'innovation, vol. 2008/2, no. 28, Economie de la Défense, Finance et Innovation, pp. 61-83.

Stephan R., 2006, "Which practices for universities to enhance exchanges and transfer?", presentation at the French American Foundation seminar "Research \& Innovation: Best Practices for the Future", University of Compiegne, Paris.

Stiglitz J., Weiss A., 1992, “Asymmetric information in credit markets and its implications for macroeconomics". Oxford Economic Papers, Vol. 44, pp. 694-724.

Teece D.J., Pisano G., Shuen A., 1997, "Dynamic capabilities and strategic management", Strategic Management Journal, vol. 18, pp. 509-533.

Veblen T., 1899, The Theory of the Leisure Class: An Economic Study in the Evolution of Institutions, tr. fr.: Théorie de la classe de loisir, Paris, Gallimard, 1970.

Veblen T., 1914, The Instinct of Workmanship, and the State of the Industrial Arts, New York, Augustus Kelley, 1963.

von Tunzelmann G.N., 1995, Technology and Progress: the Foundations of Economic Growth, Edward Elgar, Aldershot.

von Tunzelmann N., 2009, "Competencies vs. capabilities: a reassessment”, Economia PoliticaJournal of Analytical and Institutional Economics, no. 3/2009, pp. 435-464.

von Tunzelmann N., Acha V., 2005, "Innovation in 'low-tech' industries", in J Fagerberg, D Mowery and R Nelson (eds): The Oxford Handbook of Innovation, Oxford, Oxford University Press, pp. 407-432. 
von Tunzelmann N., Wang Q., 2003, “An evolutionary view of dynamic capabilities”, Economie Appliquée, vol. 16, pp. 33-64.

von Tunzelmann N., Wang Q., 2007, “Capabilities and production theory”, Structural Change and Economic Dynamics, vol. 18, pp. 192-211.

Watts D.J., Strogatz S.H., 1998, “Collective dynamics of 'small-world' networks”, Nature 393 (6684).

Weber A., 1909/1929, The Theory of Industrial Location, Chicago, University of Chicago Press.

Zimmermann J.-B., 2002, “Grappes d'entreprises et petits mondes (Company clusters and small worlds)”, Revue Economique, vol. 53, no. 3, pp. 517-524. 